\title{
Differences in acid phosphomonoesterase activity in forest soils of the Smrk Massive in the Moravskoslezské Beskydy Mts. (Czech Republic)
}

\author{
A. Bajer ${ }^{1}$, P. Samec ${ }^{2,3}$, M. Žárník ${ }^{3}$ \\ ${ }^{1}$ Department of Geology and Pedology, Faculty of Forestry and Wood Technology, Mendel University in Brno, \\ Zemédèlská 3, CZ-61300 Brno \\ ${ }^{2}$ Department of Geoinformatics, Palacký University Olomouc, tř. Svobody 26, CZ-771 46 Olomouc \\ ${ }^{3}$ Forest Management Institute Brandýs nad Labem, Nádražní2811, CZ-738 25 Frýdek-Místek
}

\begin{abstract}
Bajer A., Samec P., Žárník M. 2012: Differences in acid phosphomonoesterase activity in forest soils of the Smrk Massive in the Moravskoslezské Beskydy Mts. (Czech Republic) - Beskydy, 5 (2): 135-152

The purpose of this paper is to determine the individual relations between APEA and specific soils and environmental factors. To disclose these relations, analysis of component vectors and principal component analysis (PCA) were performed. Vectors of soil characteristics with participation of APEA $\left(\vec{a}_{A K F E}\right)$ and vectors of pedochemical variables $\left(\vec{a}_{\text {CHEM }}\right)$ were also calculated. Their ratio $\left(i_{a}\right)$ indicated the relative size of the APEA impact on the relations between pedochemical characteristics. Based on the statistical analyses, different role of APEA in Norway spruce and in European beech stands was detected. While APEA in spruce stands did not show significant correlations with the other examined soil chemical properties, soils under beech stands displayed strong correlations with some of the pedochemical variables. The idea of this research is to find out whether APEA could be used as an indicator of forest vegetation status and of the anthropogenic load on a site.
\end{abstract}

Key words: soil, acid phosphomonoesterase, principal component analysis (PCA), European beech (Fagus sylvatica L.), Norway spruce (Picea abies /L./ Karst.)

\section{Introduction and problem definition}

Acid phosphomonoesterase activity (APEA) (E.C.3.1.3.2) is one of the important indicators of forest soil carrying capacity. Phosphatases are hydrolytic enzymes releasing $\mathrm{PO}_{4}^{3-}$ from monoesters of orthophosphoric acid; however, their activity is strongly linked to $\mathrm{pH}$. Phosphatases with the optimum of activity at $\mathrm{pH}$ 4-6 are generally classified as acid phosphatases (AcP) and those with the optimum of activity at $\mathrm{pH}$ 8-12 are generally classified as alkaline phosphatases (AlP) (Rejšek 1988). Some soil organisms are able to produce acid and alkaline phosphatases simultaneously.

In naturally acid forest soils, the acid phosphatases prevail. At the same time, forest soils are predisposed by the lack of phosphorus mineral sources. Most of the pool of soil phosphorus is organically bound. Under these conditions, the ability to biochemically release available phosphorus and to metabolize it may represent a limiting factor for biosynthesis in most of the organisms within a plant association (Samec, Formánek 2007). These interrelations are particularly close in mountain environment there dead organic matter becomes a unique substrate for regeneration of whole ecosystems. Profound correlation of AcP and AlP production by the bacterial biomass and the biomass of soil mycelia is often found in F-horizon. In H-horizon, the existence of phosphatase producers significantly depends on ammonification bacteria and the organic carbon content. In contrast to that, in A-horizons, where general inhibition of biological activity occurs, the activity of phosphatases 
remains high, as well as the abundance of their microbial producers (Hýsek, Šarapatka 1998).

In forest soils, phosphatases are produced by plant roots, unicellular microorganisms, fungi and also by dead organic matter. In the conditions affected by acid deposition, changes in species composition of soil microflora (Lettl 1985), plant metabolism (Roberts et al. 1989) and activity of fungi (Leyval et al. 1997) can be observed; in addition, changing $\mathrm{pH}$ is linked to subsequent far-reaching changes of soil biological activity. In natural conditions, deficit of available phosphorus causes increased phosphatase activity leading to more intensive decomposition of P-containing substances, whereas in the environment affected by acid deposition, mycorrhizas are directly impaired and thus the activity of enzymes decreases regardless of the nutrient availability (Rejšek 1991). Under these conditions, acid deposition causes not only decline of the plant community, but also overall disturbance of its biosynthesis.

The basic tool for analysis of the APEA response to external influences is comparison of the overall activity and the activity of root exudates (Rejšek et al. 2012a). Activities of root and microbial phosphatases show different reaction kinetics, thus predetermining the subsequent efficiency of the soil phosphorus forms transformations in relation to climatic influences or pollution (Rejšek et al. 2012b). Soil units differ in their resistance to the effects of acid deposition and therefore they also provide internal environment with uneven levels of ecological stability. It is mainly the soil resilience that relates to biological activity (Formánek, Grunda 2000; Rejšek 2004). Forest soil APEA is a potential indicator of environmental changes, but at the same time, the extent of these changes is affected by permanent features of the geobiocoenoses and vegetations (Samec et al. 2006). In this study we have investigated the relations between APEA and the other soil characteristics in typical soil units and basic stand types (ST) of mountain forests. Our objective was to determine whether APEA is more differentiated in relation to soil units, soil horizons or tree species composition.

\section{Material}

The Smrk Massive ( $1276 \mathrm{~m}$ a.s.l.) is an almost totally forested area in the Moravskoslezské Beskydy Mts. comprising specially protected areas within the Protected Landscape Area Beskydy, natural and close-to-natural forests, spruce monocultures as well as stands affected by air pollution and windthrow damage (Kulhavý, Klimo 1998). Pollution load has influenced the biological activity of soil in relation to the tree species composition of forests (Samec et al. 2007). Forest phytocoenoses of the Smrk Massive also reflect the diversity of its ecotope. The Smrk Massive is the easternmost part of the Radhoštská hornatina Highland within the Moravskoslezské Beskydy Mts. formed of Godula sandstones. On the west it is separated from the Kněhyně Mt. by the Čeladenka River valley; on the east, the tectonically-formed valley of the Ostravice River separates it from the Lysá hora Massive and from the whole Lysohorská hornatina Highland. On the south it is bordered by the Zadní hory Mts., formed mainly of the Magura unit. Here, and also in the territory of the present Šance water reservoir on the Ostravice watercourse, the depressions are permanently waterlogged and are covered with typical horsetail-sphagnum spruce (Piceeta turfosa) stands and fir-sphagnum spruce (Piceeta abietina sphagnosa sup.) stands (Holuša 2007), which are scarce in the whole band of the Outer Western Carpathians (Culek 1996). In 2009, samples were taken from a set of 38 soil pits situated in Norway spruce and European beech forest stand types at the Smrk Massive and at the Kněhyně Mt. foothill (Bajer, Kučera 2011). The soil pits were located at the altitudes from 540 to $1210 \mathrm{~m}$ a.s.l. within the range from the beech to beechspruce forest vegetation tier (FVT) and within eight edaphic categories (EC). Soil classification was performed according to WRB classification (WRB-FAO 2006)

In the studied area, most of the soil pits were located in the fir-beech and the spruce-beech FVT (83\%). About $11 \%$ of the pits were placed in the conditions of the beech FVT on the northern and eastern foothill of the Smrk Massive.; only

Tab. 1: The composition of forest vegetational tiers (FVT) on localities of the soil pits (\%).

\begin{tabular}{lccccc}
\hline \multicolumn{1}{c}{ Tree species } & Beech & Fir-beech & Spruce-beech & Beech-spruce & Total \\
\hline European beech & 2.05 & 21.92 & 4.79 & & 28.77 \\
Norway spruce & 8.90 & 37.67 & 18.49 & 6.16 & 71.23 \\
\hline Total & 10.96 & 59.59 & 23.29 & 6.16 & 100.00 \\
\hline
\end{tabular}


about $6 \%$ were in the beech-spruce FVT in the top parts of the Smrk Massive (tab. 1). European beech (Fagus sylvatica L.) was found in $29 \%$ of the investigated stands, Norway spruce (Picea abies /L./ Karst.) was present in as much as $71 \%$ of the stands. Most of the soil pits were placed in the EC of mesotrophic sites (48\%). More than $10 \%$ representation of the pits was in mesotrophic stony slopes (F), mesotrophic sites (B) and skeletal sites (Y). Within the studied set of soil pits, Norway beech stands were present exclusively in the EC of the mesotrophic series, while Norway spruce stands were selected also in azonal and peat sites (tab. 2).

Relatively the most represented FTG were oligo-mesotrophic fir-beech sites (5S) and oligomesotrophic spruce-beech sites (6S), covering together more than $34 \% .12 \%$ of the sampled soil pits were placed in mesotrophic-stony fir-beech sites (5F) and $10 \%$ in mesotrophic fir-beech sites (5B). Eight soil types were found altogether in the soil pits within this study. The most frequent soil type were Cambisols (31\%). Similar frequency of $30 \%$ was found in Leptosols. Soils with the signs of podzolization process (Entic podzols and Podzols) were represented with a little smaller frequency (27\%), being more prevalent under Norway spruce stands. Leptosols were also found markedly more often under spruce stands (24\%). Azonal soils (Planosols, Gleysols and Histosols) were found exclusively under Norway spruce stands (tab. 3). On the basis of the determined soil units, the leading evident tendencies of soil development (pedogenetic processes) were characterized. The purpose of our analyses was to examine the character of the statistical dependences between APEA and other soil characteristics in the studied forest geobiocoenoses.

\section{Methods}

The statistical analyses focused on the samples of surface humus horizons $(\mathrm{O})$ and of the top-soil organic-mineral horizons (TSH). Based on the estimation of the ongoing pedogenetic processes, we selected localities showing signs of brunification and podzolization, which had the highest share among the studied pits (Bajer, Kučera 2011). The soil samples were tested for current soil acidity $\left(\mathrm{pH} / \mathrm{H}_{2} \mathrm{O}\right)$ and potential soil acidity $(\mathrm{pH} / \mathrm{KCl}$ ) acidometrically (Zbíral 2002), volumetric exchangeable acidity (VEA) by extraction in $1 \mathrm{~N} \mathrm{KCl}$ up to $\mathrm{pH} 7.8$ (Sokolov 1939), base cation content (BCC) by extraction in 0.1M BaCl 2 at $\mathrm{pH}$ of soil (Gillman 1979), cation exchange capacity (CEC) by summing and base saturation (BS) as a ratio (White 1987). The content of soil organic carbon $\left(\mathrm{C}_{\mathrm{ox}}\right)$ was determined by rapid controlled oxidation and IR-spectrophotometry (Zbíral et al. 2004) and the soil nitrogen content according to Dumas (Buckee 1994). Contents of the oxides of extractable (available) mineral nutrients were determined by Mehlich 3 extraction (Mehlich 1984). The potential APEA was specified as the speed of $\mathrm{P}^{-} \mathrm{PO}_{3}{ }^{4}$ release spectrophotometrically from control incubation of samples with substrate induction (Tabatabai, Bremner 1969).

The basic set of data was split to selections of ST and selections of soil types grouped on the basis of common pedogenetic features.

Tab. 2: The composition of edaphic categories on localities of the soil pits (\%) symbols according to VIEWEGH et al. 2003).

\begin{tabular}{lccccccccc}
\hline \multicolumn{1}{c}{} & \multicolumn{10}{c}{ Edaphic categories symbols } \\
\hline \multicolumn{1}{c}{ Tree species } & L & Y & S & B & F & A & O & R & Total \\
\hline European beech & & & 12.33 & 4.79 & 6.16 & 5.48 & & & 28.77 \\
Norway spruce & 5.48 & 10.96 & 35.62 & 5.48 & 6.16 & 1.37 & 4.11 & 2.05 & 71.23 \\
Total & 5.48 & 10.96 & 47.95 & 10.27 & 12.33 & 6.85 & 4.11 & 2.05 & 100.00 \\
\hline
\end{tabular}

Tab. 3: The composition of soil types on localities of the soil pits (\%).

\begin{tabular}{|c|c|c|c|c|c|c|c|c|c|}
\hline \multicolumn{10}{|c|}{ Soil types } \\
\hline $\begin{array}{c}\text { Tree } \\
\text { species }\end{array}$ & Leptosols & Fluvisols & Cambisols & $\begin{array}{c}\text { Entic } \\
\text { podzols }\end{array}$ & $\begin{array}{c}\text { Haplic } \\
\text { podzols }\end{array}$ & Planosols & Gleysols & Histosols & Total \\
\hline $\begin{array}{l}\text { European } \\
\text { beech }\end{array}$ & 6.16 & & 11.64 & 8.22 & 2.74 & & & & 28.77 \\
\hline $\begin{array}{l}\text { Norway } \\
\text { spruce }\end{array}$ & 23.97 & 5.48 & 19.18 & & 16.44 & 2.05 & 2.05 & 2.05 & 71.23 \\
\hline Total & 30.14 & 5.48 & 30.82 & 8.22 & 19.18 & 2.05 & 2.05 & 2.05 & 100.00 \\
\hline
\end{tabular}


Exploratory analysis was performed by linear correlation of APEA with the other soil characteristics at $P<0.05$ and $P<0.20$ and the basic descriptive quantiles were calculated. The dual level of significance serves to differentiate between the statistically well documented correlations and correlations loaded with irrelevant noise component (slight correlations or slight differences) (Samec et al. 2004). Correlations were expressed with Pearson correlation coefficient $(r)$. Initial assessment of the significance of differences in the individual characteristics between the basic selections was performed with analysis of variance (ANOVA) at $P<0.05$. A modified principal component analysis (PCA) was used to compare the differences between the multivariate analyses of the basic selections.

PCA allows extracting multivariate dependences between many variables at the same time. The output of PCA is transformation of the original variables into a set of component weights. Their number is determined by component factors. Component factors express the share of the overall variance that the individual weights represent for all variables (Senaa et al. 2002). To efficiently compare the character of the multivariate links between the soil characteristics from the individual selections and to evaluate them with the means of the same quality as in case of one-dimensional links, we simplified the multivariate information from the component weight coordinates to component vectors (SAMEC et al. 2010). Vectors of soil variables with the presence of APEA were calculated $\left(\vec{a}_{A P E A}\right)$ as well as the vectors of pedochemical characteristics $\left(\vec{a}_{\text {CHEM }}\right)$ without taking the activity of phosphatases into account. Their ratio $\left(i_{a}\right)$ indicated the relative level to which the links between the pedochemical characteristics were affected by the phosphatase activity:

$$
i_{a}=\frac{\vec{a}_{A P E A}}{\vec{a}_{C H E M}}
$$

The index of functional links of AP in forest soils $\left(i_{a}\right)$ was introduced in order to express the relative changes of interrelations between the pedochemical characteristics, if they do not take into account the biochemical activity of soil. When the component vector values of individual characteristics within the compared soil horizons had opposite signs, anomalies in the relations between the top-soil horizons were indicated. We presume that these anomalies reveal heterogeneities in the theoretically smooth transitions between two soil horizons.
The causes of these anomalies were explained by equal findings of the significantly different values of the respective soil characteristics in different ST and in aggregated soil units by linear methods.

Indexes of the relations between the pedochemical characteristics and the APEA in the selections of ST and soils were compared with one-way analysis of variance at $P<0.05$ $\left(F_{0.05}>4.13\right)$ and at $P<0.20\left(F_{0.20}>1.71\right)$. As a control, we have compared the quantiles of APEA between the individual statistical selections with two-way analysis of variance at $P<0.05$ $\left(F_{0.05}>4.20\right)$ and at $P<0.20\left(F_{0.20}>1.72\right)$ as well. Oneway ANOVA expressed the relative extent of the changes in $i_{a}$, separately between the studied ST and between the studied soil groups. Two-way ANOVA focused on identification of the interselectional differences in APEA itself. Based on the identified sources of variability and the sizes of Fischer-Snedecor $(F)$ criteria we have determined whether the differences in APEA in the monitored area of mountain forests depend more on the tree species composition or on the pedogenetic processes.

\section{Results}

Out of the basic set of 38 soil pits, we selected 31 pits with the presence of Cambisols, Leptosols, Entic Podzols and Podzols. Cambisols were found in seven Norway spruce stands and in five European beech stands. Leptosols were present in ten Norway spruce stands and in two European beech stands. Entic Podzols were in three Europaen beech stands. Podzols were found in five Norway spruce stands and in only one European beech stand (tab. 3). The selection of soils showing either signs of brunification or podzolization processes covered $82 \%$ of all sampled soil pits. Among the soils with brunification process we have included all subtypes of Cambisols and Leptosols except the podzolic subtype. Soils with podzolizacion process included Entic Podzol, Haplic Podzol and Spodic Leptosol.

In the surface humus on the brunified soils, higher contents of $\mathrm{H}^{+}, \mathrm{C}_{\mathrm{ox}}, \mathrm{N}_{\mathrm{t}}, \mathrm{Ca}^{2+}, \mathrm{K}^{+}, \mathrm{CEC}, \mathrm{BS}$ and $\mathrm{MgO}$ moderately correlated with higher APEA. The values of $\mathrm{pH}$ in brunified soils did not correlate with APEA. On the other hand, the intervals of $\mathrm{P}_{2} \mathrm{O}_{5}, \mathrm{~K}_{2} \mathrm{O}$ and $\mathrm{CaO}$ values statistically significantly correlated with the range of APEA in brunified soils. In the upper organo-mineral horizons, the activity of acid phosphomonoesterase statistically significantly correlated not only with available $\mathrm{K}_{2} \mathrm{O}$ and $\mathrm{CaO}$, but also with $B S$ and exchangeable bases. The 
relations between APEA and $\mathrm{pH}, \mathrm{H}^{+}$and $\mathrm{C} / \mathrm{N}$ were far more evident in the soils with the signs of podzolization. Simple linear correlations with exchangeable or available nutrients were not proved. The observed correlations of APEA with BS in brunified soils or with $\mathrm{pH}$ in podzolized soils were positive. They indicate that APEA is usually lower in strongly unsaturated and acid soils than in soils relatively more rich; however, this relation holds only up to the limits of AcHP optimum activity (tab. 4). Categorization of the studied soil horizons according to the dominant tree species indicated that, on one hand, Norway spruce does not significantly affect the level of relations between soil variables; on the other hand, it supports the hypothesis of positive correlation between physical-chemical soil properties and APEA in European beech forests. The monitored chemical characteristics of soil did not differ significantly between the groups of brunified and podzolized soils; however, statistically significantly different values of mainly $\mathrm{pH}, \mathrm{H}^{+}, \mathrm{C} / \mathrm{N}, \mathrm{BS}, \mathrm{K}_{2} \mathrm{O}$ and $\mathrm{CaO}$ were found between the compared ST. Significantly different values of $\mathrm{Al}^{3+}$ and $V E A$ between the ST appeared in the surface humus only. In contrast to that, the monitored APEA was statistically only slightly different between the ST; the differences between the compared groups of soils were insignificant (tab. 5).

In European beech stands, positive correlations occurred mainly between APEA and $\mathrm{pH}$, $\mathrm{Ca}^{2+}$ and $\mathrm{CaO}$. APEA and VEA including $\mathrm{H}^{+}$were in negative correlation. In the surface humus, $B S$ moderately correlated with the phosphatase activity; in TSH, the phosphatase activity was also slightly related to the contents of $\mathrm{K}_{2} \mathrm{O}$ and $\mathrm{MgO}$. Thanks to the fact that European beech humus is less acidic than that of Norway spruce, there is also higher activity of phosphatases in European beech stands. The values of APEA medians were higher in European beech stands than in Norway spruce stands. The interval of BS in surface humus under European beech stands was $40.11 \pm 24.26 \%$, in TSH it reached $14.14 \pm 6.69 \%$. In surface humus of Norway spruce stands, the BS interval was $22.30 \pm 16.33 \%$ and in TSH it did not exceed $10 \%$. The values of $\mathrm{BS}$ and $\mathrm{pH} / \mathrm{KCl}$ were absolutely the lowest in TSH under Norway spruce stands. The lowest values of median

Tab. 4: The coefficients of linear correlations between acid phosphomonoesterase activity and soil horizon chemical properties in the compared stand types and in the aggregated soil units (bold statistically significant dependence at $P<0.05$; normal statistically moderatelly significant dependence at $\mathrm{P}<0.20)$. O - surface humus; $S H$ - top-soil organic-mineral horizon.

\begin{tabular}{|c|c|c|c|c|c|c|c|c|}
\hline \multirow{3}{*}{ Quantity } & \multicolumn{4}{|c|}{ Stand type } & \multicolumn{4}{|c|}{ Soil bodies } \\
\hline & \multicolumn{2}{|c|}{ Norway spruce } & \multicolumn{2}{|c|}{ European beech } & \multicolumn{2}{|c|}{ Cambic } & \multicolumn{2}{|c|}{ Podzolic } \\
\hline & $\mathbf{O}$ & TSH & $\mathbf{O}$ & TSH & $\mathbf{O}$ & TSH & $\mathbf{O}$ & SH \\
\hline $\mathrm{pH} / \mathrm{H}_{2} \mathrm{O}$ & -0.04 & 0.24 & 0.47 & 0.56 & 0.15 & 0.21 & 0.44 & 0.95 \\
\hline $\mathrm{pH} / \mathrm{KCl}$ & -0.04 & 0.24 & 0.47 & 0.56 & 0.15 & 0.21 & 0.44 & 0.95 \\
\hline VEA & -0.07 & 0.23 & -0.66 & -0.13 & -0.14 & -0.06 & -0.48 & 0.53 \\
\hline $\mathbf{H}^{+}$ & 0.34 & 0.00 & -0.16 & -0.65 & 0.38 & -0.20 & -0.46 & -0.64 \\
\hline $\mathbf{A l}^{3+}$ & -0.21 & 0.27 & -0.58 & -0.06 & -0.31 & -0.01 & -0.23 & 0.58 \\
\hline$C_{o x}$ & 0.18 & 0.03 & 0.13 & 0.01 & 0.30 & -0.05 & -0.44 & 0.12 \\
\hline $\mathrm{C} / \mathrm{N}$ & 0.05 & -0.49 & 0.06 & -0.11 & 0.06 & -0.27 & -0.48 & -0.89 \\
\hline $\mathbf{N}_{\mathbf{t}}$ & 0.20 & 0.15 & 0.16 & 0.03 & 0.36 & 0.00 & -0.42 & 0.70 \\
\hline $\mathrm{Ca}^{2+}$ & 0.25 & 0.25 & 0.54 & 0.47 & 0.34 & 0.58 & 0.31 & 0.34 \\
\hline $\mathbf{M g}^{2+}$ & 0.06 & 0.35 & 0.21 & 0.42 & 0.07 & 0.54 & 0.01 & 0.34 \\
\hline $\mathbf{K}^{+}$ & 0.09 & 0.27 & 0.26 & 0.55 & 0.32 & 0.59 & -0.30 & 0.27 \\
\hline $\mathbf{N a}^{+}$ & -0.19 & 0.10 & 0.20 & -0.40 & 0.00 & 0.00 & -0.51 & 0.06 \\
\hline CEC & 0.14 & 0.24 & 0.27 & 0.02 & 0.28 & 0.06 & -0.31 & 0.54 \\
\hline BS & 0.22 & 0.04 & 0.50 & 0.38 & 0.29 & 0.53 & 0.43 & 0.00 \\
\hline $\mathbf{P}_{2} \mathbf{O}_{5}$ & 0.22 & -0.25 & 0.44 & -0.28 & 0.47 & -0.21 & -0.24 & -0.35 \\
\hline $\mathbf{K}_{2} \mathbf{O}$ & 0.14 & 0.22 & 0.28 & 0.53 & 0.39 & 0.49 & -0.23 & 0.31 \\
\hline $\mathrm{CaO}$ & 0.25 & -0.39 & 0.56 & 0.55 & 0.42 & 0.50 & 0.03 & -0.15 \\
\hline MgO & 0.07 & -0.16 & 0.40 & 0.51 & 0.27 & 0.40 & -0.12 & -0.28 \\
\hline
\end{tabular}


Tab. 5: Analysis of variance in elementar soil properties between compared forest stand types and between aggregated soil units (bold statistically significant diferences at $\mathrm{P}<0.05)$. O - surface humus; TSH - top-soil organic-mineral horizon.

\begin{tabular}{|c|c|c|c|c|}
\hline \multirow[t]{2}{*}{ Quality (units) } & \multicolumn{2}{|c|}{ Stand types } & \multicolumn{2}{|c|}{$\begin{array}{l}\text { Pedogenetic } \\
\text { processes }\end{array}$} \\
\hline & $\mathbf{O}$ & TSH & $\mathbf{O}$ & TSH \\
\hline $\mathbf{p H} / \mathbf{H}_{2} \mathbf{O}\left(-\log \left[\mathbf{c}\left(\mathbf{H}^{+}\right]\right)\right.$ & 14.09 & 8.34 & 0.85 & 1.09 \\
\hline pH/KCl $\left(-\log \left[\mathbf{c}\left(\mathbf{H}^{+}\right]\right)\right.$ & 14.09 & 8.34 & 0.85 & 1.09 \\
\hline $\operatorname{VEA}\left(\mathrm{cmol}^{+} / \mathrm{kg}\right)$ & 15.79 & 0.05 & 1.51 & 0.13 \\
\hline $\mathrm{H}^{+}\left(\mathrm{cmol}^{+} / \mathbf{k g}\right)$ & 10.07 & 4.81 & 1.33 & 1.01 \\
\hline $\mathrm{Al}^{3+}\left(\mathrm{cmol}^{+} / \mathrm{kg}\right)$ & 7.42 & 0.07 & 0.67 & 0.03 \\
\hline $\mathrm{C}_{\mathrm{ox}}(\%)$ & 2.66 & 0.70 & 0.01 & 0.87 \\
\hline $\mathrm{C} / \mathbf{N}(1)$ & 17.18 & 7.65 & 0.35 & 3.77 \\
\hline $\mathbf{N}_{t}(\%)$ & 0.56 & 0.00 & 0.12 & 0.15 \\
\hline $\mathrm{Ca}^{2+}\left(\mathrm{cmol}^{+} / \mathrm{kg}\right)$ & 3.34 & 23.97 & 2.15 & 0.41 \\
\hline $\mathrm{Mg}^{2+}\left(\mathrm{cmol}^{+} / \mathrm{kg}\right)$ & 0.25 & 5.85 & 1.09 & 1.68 \\
\hline $\mathrm{K}^{+}\left(\mathrm{cmol}^{+} / \mathbf{k g}\right)$ & 0.28 & 8.57 & 0.07 & 0.67 \\
\hline $\mathrm{Na}^{+}\left(\mathrm{cmol}^{+} / \mathrm{kg}\right)$ & 3.08 & 5.41 & 0.84 & 0.34 \\
\hline CEC $\left(\mathrm{cmol}^{+} / \mathrm{kg}\right)$ & 3.03 & 0.17 & 0.26 & 0.25 \\
\hline BS (\%) & 6.19 & 15.47 & 1.87 & 0.41 \\
\hline $\mathbf{P}_{2} \mathbf{O}_{5}(\mathrm{mg} / \mathrm{kg})$ & 0.03 & 1.08 & 0.02 & 0.84 \\
\hline $\mathbf{K}_{2} \mathbf{O}(\mathrm{mg} / \mathrm{kg})$ & 0.04 & 4.73 & 0.13 & 0.79 \\
\hline $\mathrm{CaO}(\mathrm{mg} / \mathrm{kg})$ & 2.00 & 13.76 & 0.51 & 0.11 \\
\hline $\operatorname{MgO}(\mathrm{mg} / \mathrm{kg})$ & 0.36 & 3.95 & 0.56 & 0.98 \\
\hline APMA ( $\mu$ g/hod.) & 0.37 & 2.59 & 1.49 & 0.03 \\
\hline
\end{tabular}

and interval estimations of APEA $(80.35 \pm 27.20$ $\mu \mathrm{g} /$ hour) were also found here. In TSH of European beech stands, APEA reached $99.07 \pm 28.59$ $\mu \mathrm{g} / \mathrm{hour}$, in brunified soils it was $86.96 \pm 24.63$ $\mu \mathrm{g} / \mathrm{hour}$ and $84.42 \pm 40.16 \mu \mathrm{g} / \mathrm{hour}$ in podzolized soils (tab. 6-7). The lowest APEA was detected in TSH under Norway spruce stands on podzolized soils.

PCA proved that only two component factors are enough to characterize the studied soil pits as they jointly covered $>50 \%$ of the total variance between the monitored soil properties. Three component factors covered as much as $72-92 \%$ of the variance between the compared characteristics. The smallest share of the variance covered was found in TSH under Norway spruce stands while the highest it was in the surface humus properties in beech stands where the first component characterized as much as $69 \%$ of the total variance. The properties of humus seem to be better predictable in European beech than in Norway spruce stands (Fig. 1). However, the presence of podzolized soils may increase the level of humus properties predictability in forest stands. According to PCA, O and TSH of podzolized soils show very similar features of the relations between the variables and with the use of three component factors they cover approximately $90 \%$ of the total variance (tab. 8; Fig. 2). Transformation of the component weights to vectors indicated that the lower share of the covered variance in soils under spruce stands could be due to the anomalies in the relations of $\mathrm{Al}^{3+}$, $\mathrm{Mg}^{2+}$ and $\mathrm{MgO}$ to the other variables. The considerable differences in the covered variation of the links between the soil horizon properties under European beech stands were caused by the anomalies in $\mathrm{Al}^{3+}$ as well, but also by anomalies in the basic characteristics of humus: $\mathrm{C}_{\text {, }}$, $\mathrm{N}_{\mathrm{t}}, \mathrm{C} / \mathrm{N}$ and BS. Anomalies between $\mathrm{pH}, V E A$, $\mathrm{C} / \mathrm{N}, \mathrm{Mg}^{2+}, \mathrm{K}^{+}$and the available nutrients took a share in the uncertainties in brunified soils. In podzolized soils, the uncertainties depended mainly on anomalies between $\mathrm{C}_{\mathrm{ox}}, \mathrm{N}_{\mathrm{t}}, \mathrm{C} / \mathrm{N}, \mathrm{Ca}^{2+}$, $\mathrm{K}^{+}$and $\mathrm{P}_{2} \mathrm{O}_{5}$ (tab. 9).

Comparison of the $i$ values indicated only moderately significant differences between the compared ST and groups of soils according to 


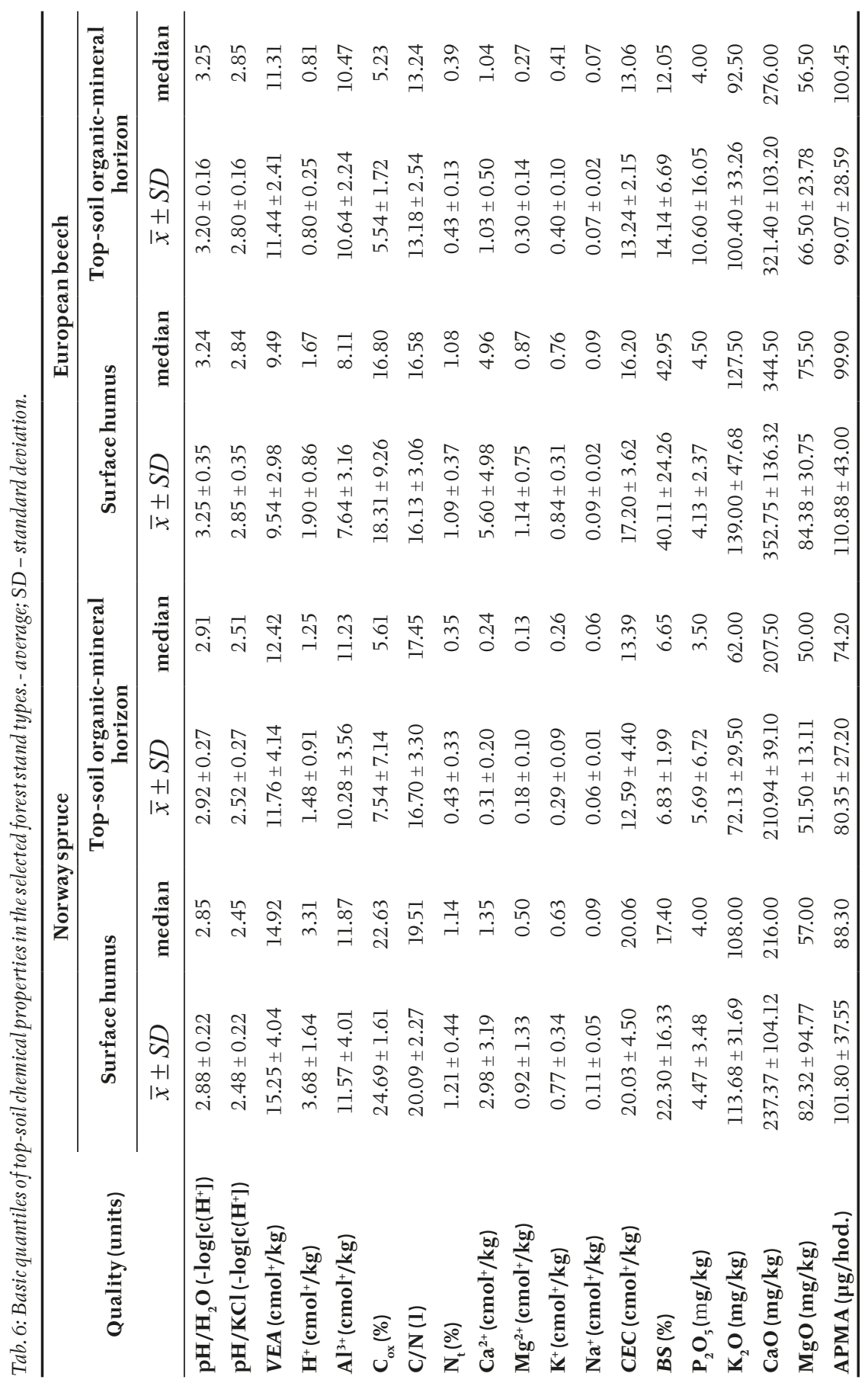




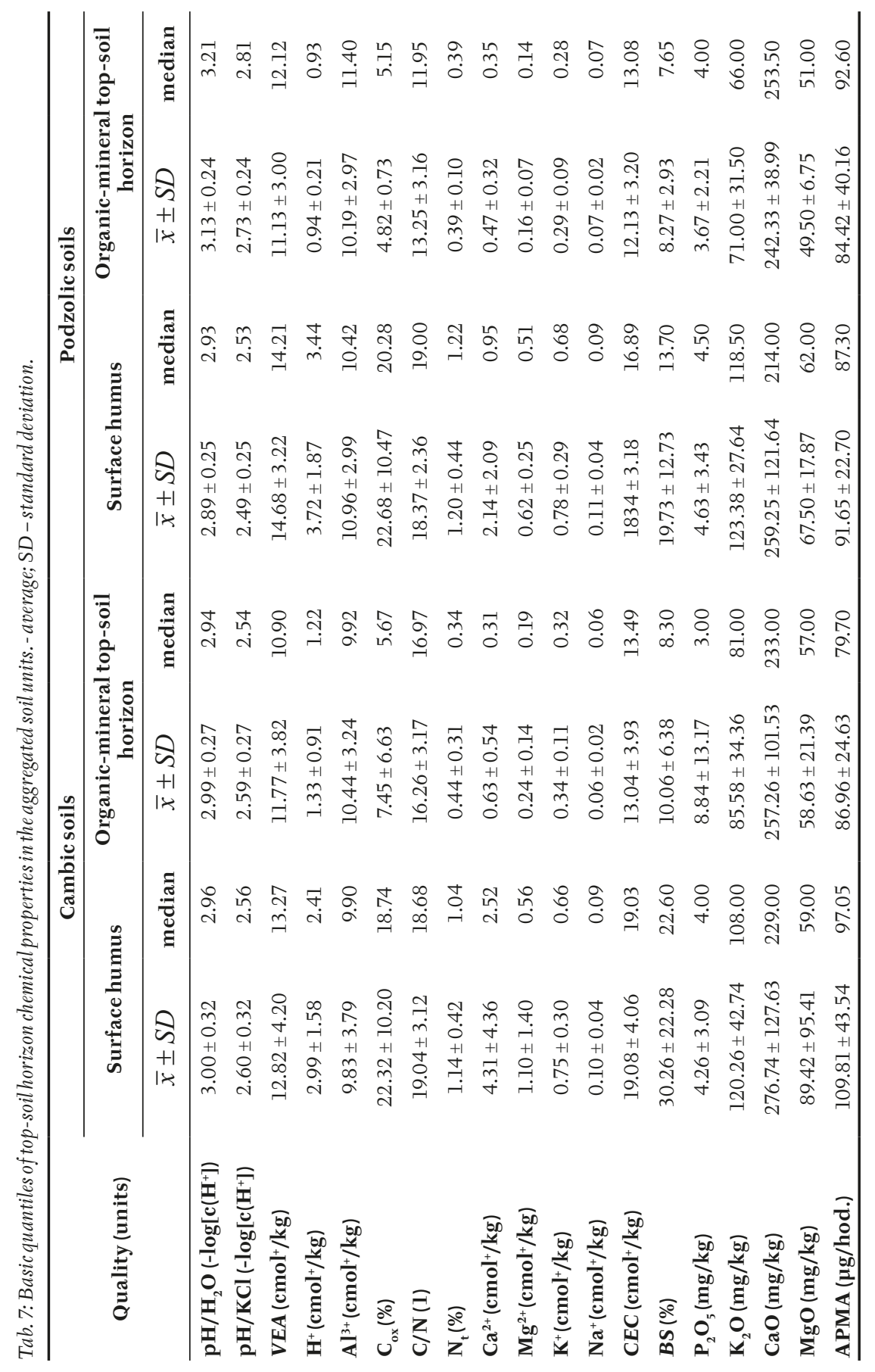



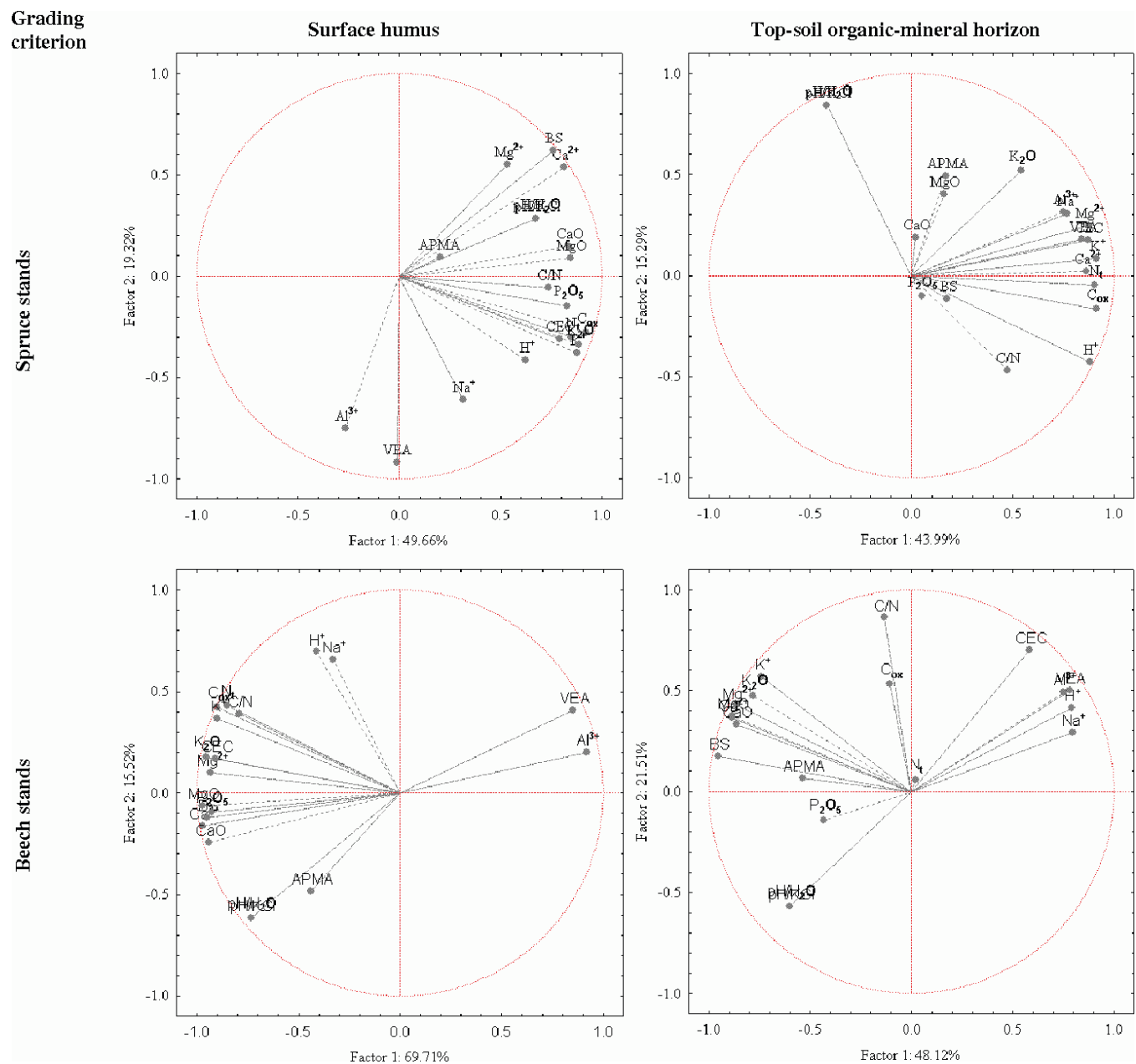

Fig. 1: Principal component analyses of pedochemical properties at surface humus and top-soil organic-mineral horizon under compared forest stand types.

pedogenetic processes. Statistical relations of APEA in surface humus were more affected by the predispositions associated with the soil body while in TSH they were influenced by the tree species. However, comparison of the APEA quantiles clearly demonstrated that the vertical differences between the individual $\mathrm{O}$ and TSH are statistically more significant than the differences resulting from the compared ST or groups of soils (tab. 10). APEA was affected to the greatest extent by transition of the soil horizons. The TSH environment has a certain effect on the influences of tree species on phosphatase activity. Higher manifestation of these influences was indicated by PCA as the increase of uncertainties. Of the TSH properties, uncertainties caused specific multivariate relations between APEA and the properties of humus substances $\left(C_{o x}\right.$ and $\left.\mathrm{N}_{\mathrm{t}}\right), B S$ and $\mathrm{P}_{2} \mathrm{O}_{5}$ in the compared ST. Linear correlation interpreted these relations between soil characteristics as theoretically insignificant.

The statistical relations between APEA and pedochemical variables are better documented when the soil horizons are divided according to pedogenetic trends. Norway spruce stands do not have a marked effect on the relations between AcP and pedochemical variables; therefore, the influences of the soil-forming substrate are manifested more here. Also the similar means and medians of the individual monitored characteristics point to the low impact of spruce stands on the properties of soil. European beech stands have a more profound effect on the relations between APEA and pedochemical characteristics, which correlate positively with $\mathrm{pH}$ and VEA in soils with the podzolization process while in case of the base cation content, 

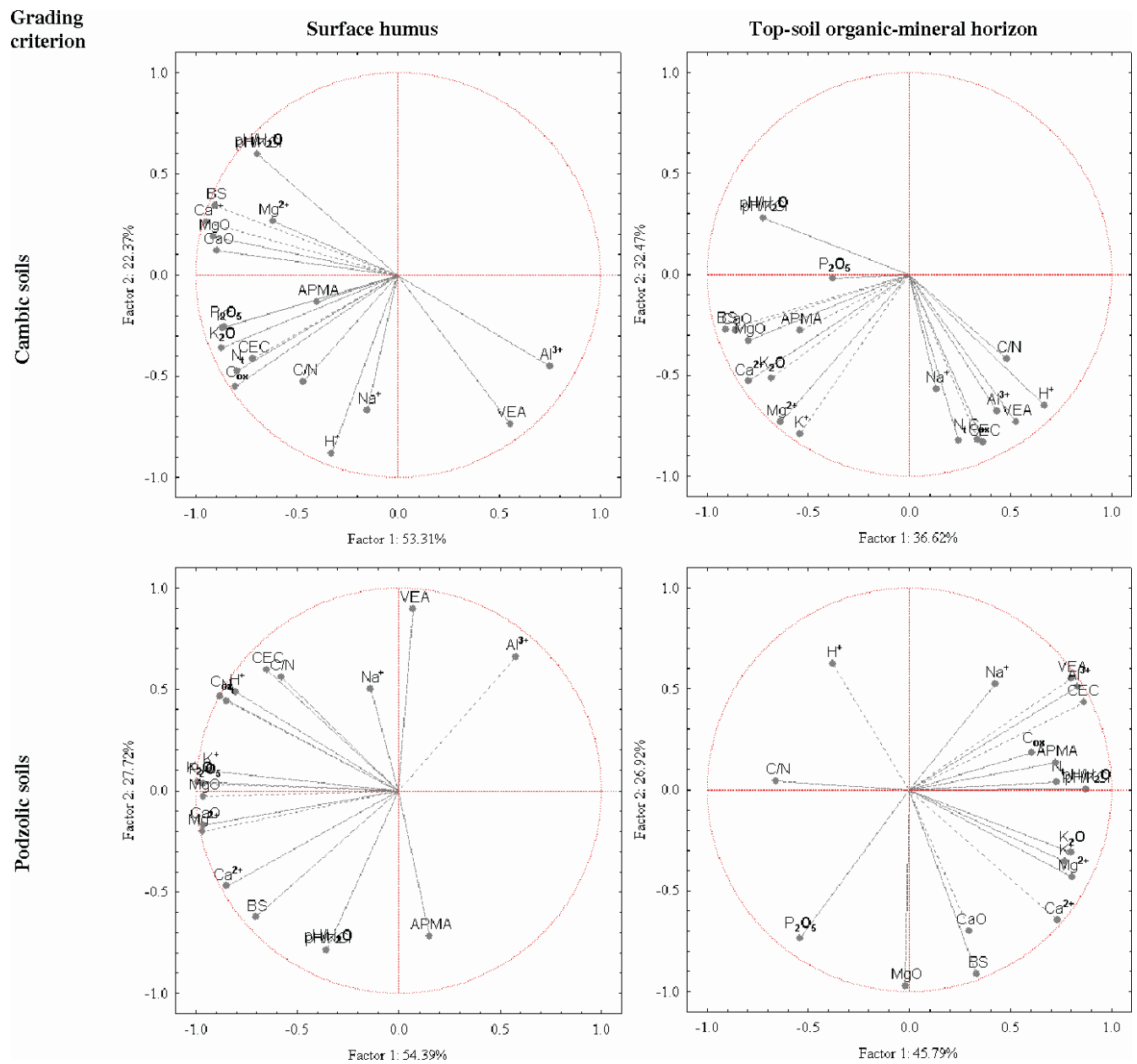

Fig. 2: Principal component analyses of pedochemical properties in surface humus and top-soil mineral horizon of the compared soil unit groups.see comentary in fig. 1

Tab. 8: Total variance at feedbacks of soil properties explained by main component factors (\%).

O-surface humus; TSH - top-soil organic-mineral horizon.

\begin{tabular}{ccccccccc}
\hline & \multicolumn{4}{c}{ Forest stand type } & \multicolumn{3}{c}{ Soil bodies } \\
\cline { 2 - 9 } Factor & \multicolumn{2}{c}{ Norway spruce } & \multicolumn{1}{c}{ European beech } & \multicolumn{2}{c}{ Cambic } & \multicolumn{2}{c}{ Podzolic } \\
\cline { 2 - 10 } & $\mathbf{O}$ & TSH & O & TSH & O & TSH & O & TSH \\
\hline $\mathbf{1}$ & 49.66 & 43.99 & 69.71 & 48.12 & 53.31 & 36.62 & 54.39 & 45.79 \\
$\mathbf{2}$ & 19.32 & 15.29 & 15.52 & 21.51 & 22.37 & 32.47 & 27.72 & 26.92 \\
$\mathbf{3}$ & 12.36 & 13.17 & 6.16 & 12.11 & 7.92 & 8.91 & 7.59 & 16.25 \\
\hline Total & 81.34 & 72.45 & 91.39 & 81.73 & 83.61 & 78.00 & 89.70 & 88.95 \\
\hline
\end{tabular}


Tab. 9: The component soil property vectors in the compared stand types and aggregated soil units. O-surface humus; TSH-top-soil organic-mineral horizon.

\begin{tabular}{|c|c|c|c|c|c|c|c|c|}
\hline \multirow{3}{*}{ Quantity } & \multicolumn{4}{|c|}{ Forest Stand type } & \multicolumn{4}{|c|}{ Soil bodies } \\
\hline & \multicolumn{2}{|c|}{ Norway spruce } & \multicolumn{2}{|c|}{ European beech } & \multicolumn{2}{|c|}{ Cambic } & \multicolumn{2}{|c|}{ Podzolic } \\
\hline & $\mathbf{O}$ & TSH & $\mathbf{O}$ & TSH & $\mathbf{O}$ & TSH & $\mathbf{O}$ & TSH \\
\hline $\mathrm{pH} / \mathrm{H}_{2} \mathrm{O}$ & 1.06 & 1.32 & 1.08 & -1.49 & 1.24 & -0.93 & -1.09 & -1.03 \\
\hline $\mathrm{pH} / \mathrm{KCl}$ & 1.06 & 1.32 & 1.08 & -1.49 & 1.24 & -0.93 & -1.09 & -1.03 \\
\hline TVK & -3.23 & -1.38 & 2.82 & 1.22 & 2.61 & -1.26 & 1.01 & 1.32 \\
\hline $\mathbf{H}^{+}$ & 1.64 & -0.99 & 15.44 & 8.28 & 1.44 & -1.24 & -0.99 & -0.98 \\
\hline $\mathbf{A l}^{3+}$ & -1.47 & 4.82 & -7.67 & 0.99 & 1.32 & 1.25 & -1.31 & -3.24 \\
\hline$C_{o x}$ & -1.20 & -1.28 & -1.12 & 8.53 & -1.18 & 0.91 & -1.06 & 0.90 \\
\hline $\mathbf{C} / \mathbf{N}$ & -1.17 & -0.72 & 5.34 & -1.04 & -13.66 & 1.01 & 1.08 & -1.11 \\
\hline $\mathbf{N}_{\mathrm{t}}$ & -5.85 & -8.92 & 1.01 & -735.12 & -4.20 & 1.06 & -0.96 & 0.84 \\
\hline $\mathrm{Ca}^{2+}$ & 1.15 & 0.92 & -1.33 & -1.34 & -1.05 & -1.01 & -11.62 & 3.17 \\
\hline $\mathbf{M g}^{2+}$ & -0.88 & 3.27 & 1.09 & 11.00 & -3.39 & 3.17 & 1.00 & 1.20 \\
\hline $\mathbf{K}^{+}$ & -0.98 & -1.08 & -1.07 & 0.99 & -1.15 & 1.03 & 0.99 & -67.72 \\
\hline $\mathbf{N a}^{+}$ & -2.82 & -1.27 & 1.35 & -9.13 & -2.96 & 15.14 & -6.21 & -0.84 \\
\hline KVK & -1.06 & -33.34 & -18.15 & -1.99 & -0.93 & -6.82 & 226 & 1.31 \\
\hline BS & 0.98 & -1.31 & 9.94 & -5.75 & -1.76 & -6.61 & -1.41 & -1.02 \\
\hline $\mathbf{P}_{2} \mathbf{O}_{5}$ & 1.95 & 0.13 & 1.65 & -0.46 & 5.90 & -0.44 & -1.11 & 1.39 \\
\hline $\mathbf{K}_{2} \mathbf{O}$ & 0.99 & -0.88 & 1.23 & 0.96 & -0.97 & 0.88 & -0.99 & 9.57 \\
\hline $\mathrm{CaO}$ & 10.92 & 0.87 & -28.66 & -1.30 & 1.67 & 1.02 & -2.95 & -0.89 \\
\hline MgO & -0.96 & 1.66 & -40.66 & -1.40 & 1.18 & -1.53 & -6.75 & -1.15 \\
\hline AKFE & -0.49 & -0.66 & 2.69 & -0.55 & 1.26 & 0.69 & 0.80 & 2.78 \\
\hline
\end{tabular}

Tab. 10: ANOVA of various functional feedbacks of the APEA in the investigated forest soils at $P<0.05$ (normal statistically moderatelly significant differences at $P<0.20$ ).

\begin{tabular}{cccc}
\hline \multirow{2}{*}{ Indicator } & \multirow{2}{*}{ Sample } & $\begin{array}{c}\text { Source of } \\
\text { variability }\end{array}$ & $\boldsymbol{F}_{\mathbf{0 . 0 5}}$ \\
\hline \multirow{2}{*}{$i_{a}$} & \multirow{2}{*}{$\mathrm{O}$} & Stand type & 0.91 \\
& \multirow{2}{*}{ TSH } & Soil body & $\mathbf{2 . 4 5}$ \\
\cline { 2 - 4 } & \multirow{3}{*}{ quantils } & Stand type & $\mathbf{1 . 7 6}$ \\
& \multirow{2}{*}{ Stand type } & Soil body & 0.67 \\
\cline { 2 - 4 } & & Tree species & 1.05 \\
& \multirow{2}{*}{ Soil } & Soil horizon & $\mathbf{2 . 0 0}$ \\
& \multirow{2}{*}{ environment } & Pedogenetics & 1.33 \\
& & Soil horizon & $\mathbf{2 . 0 3}$ \\
& & Interaction & 0.01 \\
\hline
\end{tabular}


$B S$ and available nutrients they correlate with the brunification process.

Differences in the statistical relations between APEA and the other pedochemical variables helped to indicate the extent of changes of the soil-ecological conditions in the upper part of the soil profile. Positive component vectors revealed similarities in the chemical composition of the pedons. On the other hand, the positive value in the $\mathrm{O}$-horizon and the negative value in the SH under beech stands showed that the remaining uncertainties in the character of soils in beech PT are due to inversely oriented component vectors $\mathrm{N}_{t}$ and $\mathrm{Al}^{3+}$. It is necessary to incorporate APEA into the ecological characteristics of forest soils in order to analyze the changes in the soil environment under different tree species. The tree species composition had a statistically significant effect on the specific differences between the surface humus and the organomineral horizons in brunified and podzolized soils. The observed differences may also indirectly point at the differences in forest ecology. APEA indicates that these differences are localized close to the soil surface.

\section{Discussion}

Activity of soil phosphatases is considered to be an important indicator of environmental processes (Samec, Formánek 2007; Reininger et al. 2011; Rejšek et al. 2012b). Phosphatases catalyze processes that increase the availability of phosphorus. In relation to the suitable conditions they change the rate of these processes and thus also the potential to any biosynthesis on the basis of DNA and ATP within the biocoenosis. Disturbance to the processes that increase the availability of phosphorus, especially in the situation of primarily insufficient content of $\mathrm{P}$ in weathered parent material, may hamper the production of the whole biocoenosis. As most of the soils on the territory of the Czech Republic, including the area of the Moravskoslezské Beskydy Mts., are acidic, the activity of acid phosphatases also plays an important role here. The biggest producers of acid phosphatases are moulds (Aspergillus sp.) and mycorrhizal fungi (Tarafdar et al. 2001). Acid deposition seriously damaged mycorrhizal symbiosis and thus disturbed whole forest ecosystems.

The Smrk Massive belongs to important areas of the Moravskoslezské Beskydy Mts. from the aspect of production and biology. In its upper parts there are stands, that were destroyed by windthrow disasters as well as stands regenerated on the clearings after salvage felling; at present, however, natural regeneration is appearing here and further areal decline of these stands does not occur. Critical loads of sulphur are not being exceeded here, but the critical loads of nitrogen are being exceeded by more than $4 \mathrm{~kg} / \mathrm{ha}$.year (Hettelingh et al. 2007). Although we avoided the windthrow disaster areas within the Massive when planning the distribution of the soil pits for this study, we can not rule out the influence of residual acidification on the ecology of the monitored soils as historical ecological load.

Several studies from the Kněhyně - Čertův mlýn ridge have indicated that the characteristics of soil biological and biochemical activity are more differentiated in relation to long-term changes in the species composition and structure of the forests than in response to pollution load (Samec et al. 2007). Another of the factors affecting differentiation of soil biochemical activity is the pedogenetic environment, in particular the character of the sorption complex. In naturally poor conditions, soil does not provide ideal environment for growth and the phytocoenosis development is therefore limited. One of the limiting factors of plant vitality in poor acidic conditions is the activity of $\mathrm{Al}^{3+}$. In such soil environment where the production of protons is not neutralized by bases from weathered parent material, the activity of $\mathrm{Al}^{3+}$ increases, blocking the active transmission of ions through cellular membranes. Typically, insufficient nutrition with Mg appears (Puhe, Ulrich 2001). Besides, exchangeable aluminium fills the spaces of metals in metalloenzymes during biosynthesis and so the cell produces only functionless macromolecules instead of catalysers. Spruce is highly resistant to low $\mathrm{pH}$ but very sensitive to $\mathrm{Al}^{3+}$ concentration in the sorption complex, while beech is much more tolerant to $\mathrm{Al}^{3+}$ (Ebben 1991). This explains why in beech stands, APEA is differentiated according to its links to pedochemical characteristics in both groups of the studied soils, while in spruce stands, and on podzolized soils in particular, similar phenomena were not observed. The poor soil environment in the studied area also showed the lowest activity of phosphatases. The detected moderately negative correlation between APEA and $\mathrm{Al}^{3+}$ indicated that in strongly acidic soils, APEA is usually lower as a result of higher activity of exchangeable aluminium.

Based on the fact that Norway spruce monocultures have been grown in the region for very long and on the finding that APEA is evidently different in natural and close-to-natural European beech stands, we can presume that the 
differences in APEA are partly due to the influence of spruce on soil. In the upper parts of soil profiles, marked changes in functioning of the site-forming factors occur. Soil surface is exposed to direct contact with pollutants, weather, seasonal temperature fluctuations and irregular input of organic matter. In F+H horizons, APEA is strongly linked to direct biological release of catalysers, but from A- horizons, the influence of biochemical activity of the enzymes bound to mineral particles increases. The fluctuations in temperature and moisture content also cause profound variations in the activity of humus microbes that produce enzymes only during short favourable periods but do not release them into soil and therefore they correlate with the microbial biomass. In A-horizons, the temperature and moisture content conditions are more stable; however, the availability of nutrient-rich substrates is significantly lower (in response to the decreasing content of $\mathrm{C}_{\mathrm{ox}}$ and $\mathrm{N}_{\mathrm{t}}$ ) and thus the relatively stable microbial communities and roots produce higher amount of the extracellular enzymes (Tarafdar et al. 2002). In the TSH of the monitored soils, the best detectable differences in APEA were found not only between the compared ST, but also in relation to the horizons of the upper part of the soil profile.

Significance of the APEA correlations was affected mainly by the exchangeable bonds of the phosphatase molecules with soil particles, especially in the TSH. Extracellular enzymes are vulnerable to attacks by other proteolytic enzymes. Both phosphatase and urease are present in soil mostly in the form of strongly bound complexes (Burns et al. 1972), which, on one hand, protects them against the attacks of proteolytic enzymes, on the other hand, they are permanently active (Nannipierr et al. 1979). The state of soil enzymes can be examined, for example, by determining the correlations with other soil features. Multivariate analyses allow us to monitor the functions of APEA together with the whole natural groups of soil properties. However, interpretation of the multivariate results is demanding and requires suitable simplification. ANOVA has indicated that different tree species composition is connected with the level of differentiation of chemical properties found in the upper soil horizons. In O-horizons, ANOVA calculated the differences in APEA in the compared ST as insignificant and in TSH as moderately significant. Application of multivariate methods, working with combinations of all the input variables simultaneously, enabled us to uncover the causes of this situation.
The basic multivariate technique is PCA. However, to be able to compare the series of PCA data as simply and effectively as is possible with data from one-dimensional methods, it is necessary to simplify the created set of data again. PCA extracts the variance of the relations between the combinations of all compared variables except for the part that does not correlate. It introduces new, the so-called component variables, divided into sorting (component) factors and transformed weights. These weights may be expresses in orthogonal matrix. As their mutual different positions relate to the beginning of the coordinates, Samec et al. (2010) suggested their joint expression in the form of a set of vectors that maintain the common beginning against each other and differ in the trend of the deviation. It is possible to compare the similarity of two different PCA in this form with one-way ANOVA. One of the most important advantagesof PCA is the possibility of dimensionality reduction. Dimensionality reduction manifests itself as decrease of the number of the compared variables to the part that strongly correlates (Webster 2001). In order to still reflect the real nature of the separated relations, the analyzed set of data must be input in its entirety above all. Omission of a group of variables can make correct interpretation of the influences of another variable impossible (Reid, Spencera 2009). A similar phenomenon has been observed after inclusion or omission of APEA from the set of pedochemical characteristics. Without taking account of the biochemical activity, the soil indicated different relations between the variables; however, these differences may be insignificant in some cases (Parka et al. 2006). Some of the variables included in the PCA were not obtained independently but were derived from a calculation. Nevertheless, they clearly did not cause the presence of one dominant component factor. In most of the evaluated cases, even the sum of the total incorporated variances of three factors did not reach the $90 \%$ recommended as the limit for recognition of functional relations between the compared groups of ecological variables (Hebák, Hustopecký 2004).

Biological activity of soil varies even when monitored at constant conditions and it signalizes various processes within the soil horizon with the course of time. In TSH, APEA differs mainly in relation to forest/non-forest biotopes, but also between European beech or Norway spruce stands (Samec et al. 2006). Analysis of soil dead organic matter is an important supportive characteristic for this indication as it is an easily accessible substrate for soil biota and the 
changes of its content may affect also the activity of soil enzymes. Production of humus is important for correct function of autoregulation mechanisms in forests. Humic substances developed through beech litter decompositionact like hormones stimulating beech seed germination (Pizzeghello et al. 2001). In artificialforest stands, this link is missing. Dead organic matter is a unique source of biologically available phosphorus compounds in forest stands.

As the linear correlations between APEA and the other soil characteristics indicated that they occur under beech stands only, but ANOVA did not confirm elementary differences between APEA in different ST, it was necessary to perform a complex investigation of the relations between APEA and soil environment. We have compiled the PCA of soil variables with APEA and of soil variables without APEA. Their comparison with the help of the introduced $i_{a}$ confirmed that surface humus as well as organo-mineral horizons show statistically differently distributed correlations between variables. The most marked change in the relations of the soil properties can be found on the dividing line between the surface humus and the organo-mineral horizon. This transition determined also the differences between the properties of soil in the compared geobiocenoses. Nevertheless, introduction of $i_{a}$ is only one of the potential possibilities how to mutually compare PCA with different combinations of variables. Further possibilities include calculations of differential vectors, calculation of the resultant vector or separation of relatively the most influential variable (Senaa et al. 2002). Introduction of $i_{a}$ enabled simplification of the compared datasets prior to the analysis of variance.

Simple analysis of variance of these indexes disproved neither the influence of ST, nor the effects of pedogenetic processes on the differences in APEA. According to conformities in several analyses of variance, the differences in APEA due to pedogenetic processes were of greater importance. Site conditions caused insignificance of some statistical relations of APEA in podzolic soils; therefore, the difference between Norway spruce and European beech forest stand type was distinguishable in brunified soils only. Differences in suitability of living conditions for microbial producers of AcP were indicated by means of the difference in linear correlations between the phosphatase activity and $\mathrm{C} / \mathrm{N}$. The strongest correlation at $P<0.05$ was found in TSH of podzolized soils: its negative character shows that in the conditions of unfavourably high $\mathrm{C} / \mathrm{N}$, APEA is low. The $\mathrm{C} / \mathrm{N}$ values are inversely proportional also to soil biological activity (Fleger, Schrader 2000). Therefore, low APEA also potentially points to low biological activity of microbes. Similarly, the low values of APEA also corresponded with higher content of $\mathrm{Al}^{3+}$ in mainly podzolized soils. Presence of Norway spruce stands on these sites was not reflected in any significant effect that could be indicated by linear correlation. In European beech stands, however, differences in APEA and in some pedochemical characteristics were detected, implying the ability to form interactions with the environment even in poor soil conditions. The impacts of European beech on biochemical properties of TSH could manifest themselves mainly due to stabilization of enzymes on the surface of soil particles. In surface humus, the most important differences in correlations were due to the content of $\mathrm{Al}^{3+}$ which was affected by the pedogenetic process and the $\mathrm{C} / \mathrm{N}$ in vegetation litter.

\section{Conclusion}

Within the study of soil conditions in European beech and Norway spruce forest stand types covering the Smrk Massive (540-1210m a.s.l.), one-dimensional and multivariate methods of statistical analysis derived from PCA were compared. One-dimensional linear methods were applied to detect correlations between APEA and other soil characteristics. PCA was used for basic examination of mutual links between all of the monitored variables. The suggested index expressing the ratio of statistical links between pedochemical variables including APEA and between pedochemical variables without APEA $(i)$ was used for grouping and simplification of the multivariate information on the monitored forest soils. Omission of APEA means that mainly $\mathrm{C}_{\mathrm{ox}}, \mathrm{N}_{\mathrm{t}}$, exchangeable potassium and available phosphorus will indicate qualitatively different relations with the ambient environment.

In soils under spruce stands, APEA maintains mostly insignificant correlations with the other studied chemical characteristics, while in soils under European beech stands; it correlates significantly with some of the pedochemical variables. Application of $i$ allowed us to identify the probable causes of the observed differences. The lowest values of APEA were found in Norway spruce stand types in podzolized soils where the high content of exchangeable aluminium $\left(\mathrm{Al}^{3+}\right)$ acts as one of the important negative factors. In contrast, varying APEA in the surface humus horizons of Norway spruce 
and European beech stands is clearly linked to unequal $\mathrm{pH}$. Higher activity was detected in beech humus. Evidently closer statistical relation between APEA and pedochemical characteristics in beech stands compared to mostly insignificant correlations in spruce stands has been confirmed. The character of these soil links is complicated by the $\mathrm{Al}^{3+}$ and $\mathrm{N}_{\mathrm{t}}$ interactions. Differences in the statistical relations of APEA in the surface humus horizons in response to permanent soil features (pedogenetic processes) were found, in contrast to the differences of APEA relations in the organo-mineral horizons according to stand types. European beech

\section{Literature}

Bajer, A., Kučera, A. 2011: Soil characteristics of selected localities on Smrk Mt. and Kněhyně Mt. in the Moravian-Silesian Beskids (Czech Republic). Beskydy, 4: 59-72.

BuCKEE, G. K. 1994: Determination of total nitrogen in barley, malt and beer by Kjeldahl procedures and the Dumas combustion method - Collaborative trial. Journal of the Institute of Brewing, 100: 57-64.

Burns, R. G., Pukite, A. M., McLaren, A. D. 1972: Concerning the location and the persistence of soil urease. Soil Science Society of America Proceedings, 36: 308-311.

Culek, M. (ed.) 1996: Biogeografické členèní České republiky [The biogeographical division of the Czech Republic]. Enigma, Praha. 346 pp.

Eввеn, U. 1991: Die toxische wirkung von aluminium auf das wachstum und die elementgehalte der feinwurzeln von altbuchen und altfichten. Berichte des Forschungszentrums Waldökosysteme, A 64: 107 pp.

Flegel, M., Schrader, S. 2000: Importance of food quality on selected enzyme activities in earthworm casts (Dendrobaena octaedra, Lumbricidae). Soil Biology \& Biochemistry, 32: 1191-1196.

FormÁneK, P., GRUNDA, B. 2000: Sezónní změny dusíku a biologická aktivita v lesní půdě Moravskoslezských Beskyd [Seasonal changes of nitrogen and biological activity in the forest soil of the Moravskoslezské Beskydy Mts.]. Journal of Forest Science, 46: 425-435.

Gillman, G. P. 1979: A proposed method for the measurement of exchange properties of highly weathered soils. Australian Journal of Soil Research, 17: 129-139. humus potentially reduces the negative impacts of soil environment chemical properties on APEA. In Norway spruce humus, this ability did not prove; therefore, APEA can be regarded also as a perspective differential variable in the research of forest ecology.

\section{Acknowledgement}

The presented study has been supported by the Education for Competitiveness Operational Programme - the European Social Fund (project CZ.1.07/2.3.00/20.0170 of the Ministry of Education, Youth and Sports of the Czech Republic).

НевÁк, P., Нustopecký, J. 2004: Vícerozmérné statistické metody [Multivariate statistical methods]. Informatorium, Praha. 256 pp.

Hettelingh, J. P., Posch, M., Slootweg, J., Reinds, G. J., SPRANGer, T., TARRAson, L. 2007: Critical Loads and Dynamic Modelling to Assess European Areas at Risk of Acidification and Eutrophication. Water, Air and Soil Pollution Focus, 7: 379-384.

HolušA, O. 2007: Příspěvek k poznání fauny pisivek (Insecta: Psocoptera) Př́rodní rezervace V Podolánkách v Moravskoslezských Beskydech (Beskydský bioregion, Česká republika) [Contribution to the knowledge of the fauna of psocids (Insecta: Psocoptera) in the Natural Reserve „V Podolánkách“ in the Moravskoslezské Beskydy Mts. (Beskydský biogeographical region, Czech Republic]. Práce a studie muzea Beskyd (Př́rodní védy), 19: 127-141.

HÝsek, J., ŠarapatKa, B. 1998: Relationship between phosphatase active bacteria and phosphatase activities in forest soils. Biological Fertility of Soils, 26: 112-115.

KulhavÝ, J., Klimo, E. 1998: Soil and Nutrition status of forest stands under various site conditions of the Moravan-Silesian Beskids. Chemosphere, 36: 1113-1118.

LetTl, A. 1985: Kvalitativní změny mikroflóry smrkových porostů ovlivněných průmyslovými imisemi $\mathrm{SO}_{2}$ [Qualitative changes in the microflora of the spruce stands exposed to $\mathrm{SO}_{2}$ emissions]. Lesnictví, 31: 187-202.

Leyval, C., Turnau, K., Haselwandter, K. 1997: Effects of heavy metal pollution on mycorrhizal colonization and function: physiological, ecological and applied aspects. Mykorrhiza, 7: 139-153. 
Menlich, A. 1984: Mehlich 3 soil test extractant: A modification of Mehlich 2 extractant. Comunication in Soil Science and Plant Analysis, 15: 1409-1416.

Nannipieri, P., Pedrazzini, F., Arcara, P. G., PioVANELLI, C. 1979: Changes in amino acids, enzyme activities, and biomasses during soil microbial growth. Soil Science, 127: 26-34.

Parka, S., Kub, Y. K., Seob, M. J., Kimb, D.Y., Yeonb, J. E., Leeb, K. M., Jeongb, S.-C., Yoonb, W.K., Harc, C. H., Kimb, H. M. 2006: Principal component analysis and discriminant analysis (PCA-DA) for discriminating profiles of terminal restriction fragment lenght polymorphism (T-RFLP) in soil bacterial communities. Soil Biology \& Biochemistry, 38: 2344-2349.

Pizzeghello, D., Nicolini, G., Nardi, S. 2001: Hormone-like activity of humic substances in Fagus sylvaticae forests. New Phytologist, 151: 647-657.

Pune, J., Ulrich, B. 2001: Global climate change and human impacts on forest ecosystems: postglacial development, present situation, and future trends in Central Europe. Springer-Verlag Berlin Heidelberg. $591 \mathrm{pp}$.

ReID, M. K., SPENCERA, K. L. 2009: Use of principal component analysis (PCA) on estuarine sediment datasets: The effect of data pre-treament. Environmental Pollution, 157: 2275-2281.

Reininger, D., Fiala, P., Malý, S. 2011: Vybrané mikrobiální a enzymatické parametry v typech lesních půd [Selected microbial and enzymatic parameters in the forest soils types]. In: Sовоска́ J. (ed.), Diagnostika, klasifikácia a mapovanie pôd. VÚPOP Bratislava: 70-75 pp.

REJŠEK, K. 1988: Fosfatázy v lesních půdách (přehled literatury) [Phosphatases in forest soils (Literature survey)]. Acta Universitatis Agriculturae, 57: 59-83.

REJŠEK, K. 1991: Acid phosphomonoesterase activity of ectomycorrhizal roots in Norway spruce pure stands exposed to pollution. Soil Biology \& Biochemistry, 23: 667 - 671.

REJŠEK, K. 2004: The HadCM2 climate change model, elevated $\mathrm{CO}_{2}$ model (SRES A2) and asseessment on their likely impacts on forest soils in the Czech Republic. Ekológia (Bratislava), 23: 80-87.

Rejšek, K., Vranová, V., Formánek, P. 2012a: Determination of the proportion of total extracellular acid phosphomonoesterase (E.C. 3.1.3.2) activity presented by roots in the soil of different forest ecosystems. The Scientific World Journal, 12: 250805.
RejŠek, K., Vranová, V., Pavelka, M., Formánek, P. 2012b: Acid phosphomonoesterase (E.C. 3.1.3.2) location in soil. Journal of Plant Nutrition and Soil Science, 175: 196-211.

Roberts, T. M., Skeffington, R. A., Blank, L. W. 1989: Causes of Type 1 Spruce Decline in Europe. Forestry, 62: 179-222.

SAMEC, P., Formánek, P. 2007: Mikrobiologie lesnich puid [Microbiology of forest soils]. Lesnická práce, Kostelec nad Černými lesy. 126 pp.

Samec, P., Kučera, A., Kisza, L., DañKová, E., KoblížKová, V., Formánek, P. 2006: Časová proměnlivost biologické aktivity organominerálních horizontů půd z různých typů biotopů jedlo-bukového lesního vegetačního stupně Moravskoslezských Beskyd během uchování v laboratorních podmínkách [Temporal variability of biological activity on soil organo-mineral horizons from fir-beech forest altitudinal zone of the Moravan-Silesian Beskids Mts. evaluated under laboratory conditions]. Zprávy lesnického výzkuтu, 51: 162- 171.

SAmec, P., VavŘíček, D., Skoták, V., Formánek, P., KIsza, L. 2007: Aktivita katalázy v lesních půdách Moravskoslezských Beskyd [Catalase activity in forest soils of the MoravanSilesian Beskids]. Práce a studie muzea Beskyd (Př́rodnívédy), 19: 237-248.

SAmec, P., VavŘ́́č́̌e, D., Bojko, J., ŽID, T. 2010: Soil component vectors in the southwestern Silesian Beskids. Electronical Journal of Polish Agricultural Universities, 13: \#14.

Samec, P., Vranová, V., Formánek, P. 2004: Problems of the statistical evidence of feedbacks between forest herb phytocoenoses and soil acidity at pollution load. Journal of Forest Science, 50: 478-488.

SenaA, M. M., Frighettob, R. T. S., Valarinib, P. J., Tokeshic, H., Poppi, R. J. 2002: Discrimination of management effects on soil parameters by using principal component analysis: a multivariate analysis case study. Soil and Tillage Research, 67: 171-181.

Soкоlov, A. V. 1939: Determinacia izmenenia glinozema v podach. Chemizacija socialističeskogo zemledelija, 7:30-35.

Tarafdar, J. C., Yadav, R. S., Meera S. C. 2001: Comparative efficiency of acid phosphatase originated from plant and fungal sources. Journal of Plant Nutrition Soil Science, 164: 279-282.

Tabatabai, M. A., Bremner, J. M. 1969: Use of $p$ nitrophenylphosphate for assay of soil phosphatase activity. Soil Biology \& Biochemistry, 1 : 301-307. 
TARafdar, J. C., Yadav, R. S., Niwas, R. 2002: Relative efficiency of fungal intra- and extracellular phosphatases and phytase. Journal of Plant Nutrition Soil Science, 165: 17-19.

Viewegh, J., Kusbach, A., Mikeska, M. 2003: Czech forest ecosystem classification. Journal of Forest Science, 49: 85-93.

WeBSTER, R. 2001: Statistics to support soil research and their presentation. European Journal of Soil Science, 52: 331-340.
White, R. E. 1987: Introduction to the Principles and Practice of Soil Science. Blackwell Scientific Publications, Oxford. 384 pp.

WRB-FAO 2006: World Reference Base for soil resources. FAO Roma.

ZBíral, J. 2002: Analýza piod I. Jednotné pracovní postupy [Soil Analysis I. Method operations]. ÚKZÜZ, Brno. 197 pp.

Zbíral, J., Honsa, I., Malý, S., Čižmár, D. 2004. Analýza pid III. Jednotné pracovní postupy [Soil Analysis III. Method operations]. ÚKZÚZ, Brno. 199 pp. 